\title{
Expression of growth factors and remodelling of the airway wall in bronchial asthma
}

\author{
Makoto Hoshino, Yutaka Nakamura, Joe Joon Sim
}

\begin{abstract}
Background - Bronchial asthma is characterised by airway structural changes, including mucosal inflammatory infiltration and subepithelial collagen deposition, that may represent the morphological basis for the chronicity of the disease. The relationship between airway wall thickness and growth factors in asthma has not been elucidated.

Methods - Bronchial biopsy specimens were obtained from 21 asthmatic patients and eight healthy subjects and the basement membrane thickness was measured by light microscopy and electron microscopy. At the same time the numbers of eosinophils and fibroblasts were assessed and the expression of transforming growth factor $\beta_{1}\left(\right.$ TGF $\left.-\beta_{1}\right)$, platelet derived growth factor (PDGF), and insulin like growth factor (IGF) $I$ in the bronchial mucosa was examined by immunostaining. The relationship between the degree of thickening of the subepithelial layer and both the clinical data and pulmonary function were also investigated.
\end{abstract}

Results - The basement membrane of the asthmatic patients was thicker than that of the healthy controls (median 8.09 versus $4.02 \mu \mathrm{m})$. Electron microscopic examination of the basement membrane revealed thickening of the subepithelial lamina reticularis; this thickening significantly correlated with the number of fibroblasts in the submucosa in the asthmatic subjects $\left(r_{s}=0.88\right)$ but not in the controls $\left(r_{s}=0.70\right)$. There was a significantly higher number of eosinophils in the airways of the asthmatic subjects than in the healthy subjects (EG1 + cells: 52.0 versus $2.0 / \mathrm{mm}^{2}$, EG2 + cells: 56.0 versus $1.5 / \mathrm{mm}^{2}$ ). The expression of each growth factor in the bronchial mucosa was similar in asthmatic and healthy subjects (TGF- $\beta_{1}: 18.0 \%$ versus $16.0 \%$, PDGF: $37.0 \%$ versus $32.5 \%$, IGF-I: $15.0 \%$ versus $8.0 \%$ ). A weak but statistically significant correlation was found between the number of fibroblasts and the expression of TGF- $\beta_{1}$ in asthmatic subjects $\left(r_{s}=0.50\right)$. There was a significant correlation between the thickness of the subepithelial layer in asthmatic subjects and the attack score $\left(r_{s}=0.58\right)$ and a significant inverse correlation between the subepithelial collagen thickness in asthmatic subjects and airway hypersensitivity $\left(r_{s}=-0.65\right)$.

Conclusions - These findings indicate that the thickening of the subepithelial layer in bronchial asthma is due to an increase in fibroblasts, and that the thickness of the subepithelial collagen appears to be linked to an increase in bronchial responsiveness and exacerbation of clinical manifestations.

(Thorax 1998;53:21-27)

Keywords: bronchial asthma, growth factors, fibroblast, remodelling of airway wall.

Identification of the histopathological features of bronchial asthma has been largely based on the results of necropsy studies which have documented epithelial cell shedding, inflammatory cell infiltrate with numerous eosinophils, ${ }^{12}$ and subepithelial collagen thickening. It has now become clear that this phenomenon occurs in mild atopic asthma, even in patients with a relatively short clinical history. ${ }^{3}$ In patients with asthma chronic inflammation determines pathological changes in the airways and causes marked remodelling of the structure of the bronchi. ${ }^{4}$ Bronchial biopsy specimens from asthmatic patients have indicated that the typical remodelling of the airways is caused by thickening of the subepithelial layer. ${ }^{5}$ This view has persisted, despite ultrastructural studies showing that the true epithelial basement membrane was normal and that the thickening was due to deposition of fibrillar collagen species, leading to an increase in depth and density of the lamina reticularis beneath the basement membrane ${ }^{67}$ Further studies using antibodies to different types of collagen have revealed an increase in the amount of interstitial collagen types I, III, and V and fibronectin in the thickened basal lamina of patients with asthma. $^{5}$ The thickening of the subepithelial layer is associated with an increase of myofibroblasts. ${ }^{8}$ Fibroblasts are key cells for the secretion of extracellular matrix components and a number of growth factors appear to be important for the proliferation of fibroblasts in the lung. ${ }^{9}$ However, no reports on the relationship between airway remodelling and growth factors in asthma have been published.

To investigate the nature and extent of airway remodelling we examined fibreoptic bronchial biopsy specimens from asthmatic patients. We assessed the degree of subepithelial thickening by light and electron microscopy, determined the number of fibroblasts present, and investigated expression of the contributing growth factors by immunohistochemistry. Furthermore, we related the degree of thickening of the subepithelial layer to indices of disease duration, activity, and airway hyperresponsiveness. 
Table 1 Characteristics of asthmatic subjects

\begin{tabular}{|c|c|c|c|c|c|c|c|c|}
\hline $\begin{array}{l}\text { Patient } \\
\text { no. }\end{array}$ & $\begin{array}{l}\text { Age } \\
\text { (years) }\end{array}$ & Sex & $\begin{array}{l}I g E \\
(I U / m l)\end{array}$ & $\begin{array}{l}\text { Score } \\
\text { (lday) }\end{array}$ & $\begin{array}{l}\text { PEF diurnal } \\
(\%)\end{array}$ & $\begin{array}{l}F E V_{1} \\
\text { (\%pred) }\end{array}$ & $\begin{array}{l}\text { Dmin } \\
\text { (unit) }\end{array}$ & $\begin{array}{l}\text { Duration } \\
\text { (years) }\end{array}$ \\
\hline 1 & 26 & $\mathrm{~F}$ & 968.3 & 3.7 & 33.3 & 73.1 & 2.37 & 1 \\
\hline 2 & 44 & M & 507.1 & 4.7 & 33.8 & 50 & 1.32 & 19 \\
\hline 3 & 48 & $\mathrm{~F}$ & 125.4 & 3.6 & 17.1 & 63.7 & 3.64 & 1 \\
\hline 4 & 42 & $\mathrm{~F}$ & 1207.8 & 4.1 & 24 & 55.9 & 2.05 & 2 \\
\hline 5 & 20 & M & 1288.6 & 5.6 & 10.5 & 77.3 & 3.08 & 15 \\
\hline 6 & 21 & M & 239.6 & 5.0 & 25 & 93.6 & 0.89 & 11 \\
\hline 7 & 23 & M & 523.5 & 2.2 & 29.6 & 86.5 & 2.19 & 21 \\
\hline 8 & 43 & M & 119 & 3.4 & 16.3 & 73.1 & 3.76 & 25 \\
\hline 9 & 23 & M & 208 & 3.0 & 28.6 & 61.9 & 3.36 & 20 \\
\hline 10 & 33 & $\mathrm{M}$ & 1803 & 9.9 & 31.0 & 77.1 & 1.0 & 30 \\
\hline 11 & 23 & M & 352.9 & 2.6 & 14.5 & 85.6 & 3.39 & 18 \\
\hline 12 & 25 & M & 1131 & 3.0 & 32.8 & 52.9 & 0.82 & 20 \\
\hline 13 & 23 & M & 253.2 & 14.0 & 46.6 & 67.5 & 0.93 & 5 \\
\hline 14 & 40 & $\mathrm{~F}$ & 171 & 5.3 & 33.3 & 59.6 & 1.09 & 2 \\
\hline 15 & 19 & M & 1401 & 4.6 & 10.5 & 71.1 & 2.29 & 14 \\
\hline 16 & 16 & M & 531.6 & 5.6 & 17.4 & 50 & 1.22 & 2 \\
\hline 17 & 18 & M & 1953.6 & 4.6 & 22.0 & 65.5 & 0.56 & 16 \\
\hline 18 & 25 & M & 999.9 & 5.9 & 37.2 & 77.6 & 1.68 & 20 \\
\hline 19 & 18 & M & 606 & 10.4 & 42.1 & 89.6 & 0.54 & 13 \\
\hline 20 & 17 & M & 1548.1 & 9.5 & 21.8 & 87.2 & 1.99 & 1 \\
\hline 21 & 30 & M & 1507.5 & 3.6 & 30.7 & 62 & 2.48 & 25 \\
\hline Mean (SD) & $27(10)$ & & $830.7(594.6)$ & $5.5(3.0)$ & $26.5(9.9)$ & $70.5(13.3)$ & $1.93(1.05)$ & $13(9)$ \\
\hline
\end{tabular}

Score $=$ attack score (daily mean of the sum of 8 symptoms); PEF diurnal = diurnal variation in peak expiratory flow; Dmin $=$ minimum dose of methacholine as the indicator for bronchial sensitivity; unit $=$ equal to one minute of $1.0 \mathrm{mg} / \mathrm{ml}$ aerosol inhalation of methacholine.

\section{Methods}

SUBJECTS

Asthma was defined as a clinical history of intermittent chest tightness, wheezing, coughing, or shortness of breath and documented reversible airflow obstruction $(20 \%$ improvement in peak expiratory flow (PEF) or forced expiratory volume in one second $\left(\mathrm{FEV}_{1}\right)$, either spontaneous or in response to inhaled $\beta_{2}$ agonists). All patients satisfied the American Thoracic Society criteria for asthma. ${ }^{10}$ None had received inhaled or orally administered corticosteroids or any other anti-inflammatory drugs such as sodium cromoglycate or nedocromil sodium in the previous four months. The mean $\mathrm{FEV}_{1}$ was $70.5 \%$ (range 50-93.6\%) of the predicted values. The clinical details of all patients are shown in table 1. The duration of their symptomatic asthma ranged from 1 to 30 years. Twenty one asthmatic patients (17 men) aged $17-48$ years (mean 27 years) were recruited from our hospital. Patients used inhaled $\beta_{2}$ stimulants only when necessary. Current smokers and patients with $<50 \%$ of predicted $\mathrm{FEV}_{1}$ were excluded. Patients showed no signs of upper or lower respiratory disease for at least two weeks before entering the study.

Eight healthy, non-smoking volunteers from the hospital staff (five men) aged 19-48 years (mean 31 years) were used as controls. All controls had normal airway reactivity and a mean $\mathrm{FEV}_{1}$ of $89.0 \%(84.3-97.1 \%)$ of the predicted values.

The study protocol was approved by the ethics committee of Toho University School of Medicine and written informed consent was obtained from all subjects.

STUDY DESIGN

At the initial visit a full history was obtained. Skin prick tests to common aeroallergens (house dust mite, cat fur, dog fur, and grass pollen) were performed and blood was taken for measurement of total and specific $\operatorname{IgE}$ (Phadebas RAST; Pharmacia, Uppsala, Sweden). Asthmatic subjects measured their PEF in the morning and evening using a Personal Best Peak Flowmeter (Health Scan, Cedar Grove, New Jersey, USA) and recorded results on a diary card. The results of PEF measurements were expressed as the best measurements taken and the diurnal variation in PEF was expressed as the mean value of two weeks calculated from the highest minus the lowest daily value, divided by the mean. Eight symptom scores were recorded daily on the diary card: nocturnal wheeze; nocturnal cough; morning chest tightness; wheezing during the day; limitation of activity; and the effect of exercise, cold air, and dust on asthma symptoms. A scoring system ranging from 0 to 3 was used with $0=$ none, $1=$ mild, $2=$ moderate, and $3=$ severe. The results were expressed as the daily mean of the sums of the eight scores. The number of inhalations of salbutamol (Glaxo, Tokyo, Japan) taken as required were recorded on the diary card. The mean initial symptom scores and $\beta_{2}$ usage were calculated for a two week observation period.

After six days patients returned having abstained from inhaling $\beta_{2}$ agonists for at least 12 hours. Spirometric tests were performed and methacholine inhalation test measurements were taken according to the method of Takishima et al. ${ }^{11}$ Briefly, using an "Astograph" (TCK-6000CV, Chest MI Co, Tokyo, Japan) the dose-response curves of respiratory resistance were determined. Baseline values were measured after the inhalation of an isotonic saline solution, then increasing concentrations of methacholine hydrochloride in isotonic saline were inhaled starting at a concentration of $49 \mu \mathrm{g} / \mathrm{ml}$ and increasing stepwise to $25000 \mu \mathrm{g} / \mathrm{ml}$. The cumulative dose that was administered at the point where the reciprocal of the respiratory resistance decreased linearly was the measurement of bronchial sensitivity (Dmin). After a further six days the patients returned to the hospital and fibreoptic bronchoscopy was performed.

FIBREOPTIC BRONCHOSCOPY

Premedication with $0.5 \mathrm{mg}$ atropine sulphate i.m. and $15 \mathrm{mg}$ pentazocine was administered 
to subjects. After the throat had been anaesthetised with $4 \%$ lignocaine spray the subjects inhaled $200 \mu \mathrm{g}$ of salbutamol to prevent bronchoconstriction. A bronchoscope (BF type 20, Olympus Co, Tokyo, Japan) was inserted through the mouth. The pharynx, trachea and bronchi were anaesthetised with $2 \%$ lignocaine. Oxygen at $41 / \mathrm{min}$ was administered via nasal cannulae throughout the procedure. Biopsy forceps (FB-15C, Olympus) were used to collect 2-3 biopsy specimens from the spur of a basal segment bronchus of the right lower lobe and from the subcarina of the right upper lobe. Inhalation of $200 \mu \mathrm{g}$ salbutamol was administered after the procedure. All subjects tolerated the procedure well and there were no instances of bronchoconstriction.

\section{BIOPSY SAMPLES}

Biopsy specimens for light microscopy were mounted in an OCT compound (Miles Scientific, Naperville, Illinois, USA), frozen rapidly in dry ice-acetone, and stored at $-70^{\circ} \mathrm{C}$. Biopsy specimens for electron microscopy were fixed immediately in $2 \%$ glutaraldehyde $/ 1.4 \%$ formaldehyde fixative at $4{ }^{\circ} \mathrm{C}$ for two hours in $0.1 \mathrm{M}$ cacodylate buffer at $\mathrm{pH}$ 7.2.

\section{LIGHT MICROSCOPY}

Sections $4 \mu \mathrm{m}$ thick were stained using the streptavidin-biotin peroxidase technique (Dako Ltd, High Wycombe, UK). Sections were treated with $0.3 \% \mathrm{H}_{2} \mathrm{O}_{2}$ in methanol for 10 minutes to block endogenous peroxidase, and then for a further 30 minutes with $2 \%$ normal porcine serum to suppress non-specific absorption of immunoglobulins. After rinsing with phosphate buffered saline (PBS) the sections were incubated with the primary monoclonal or polyclonal antibodies overnight at $4^{\circ} \mathrm{C}$. The following monoclonal antibodies were used: EG1 (Pharmacia) for total eosinophils which recognises the stored form of cationic protein; EG2 (Pharmacia) for activated eosinophils which recognises the cleaved form of cationic protein; anti-human fibroblast (Biomeda Corp, Forster, California, USA) for fibroblasts which reacts with the $\beta$ subunit of prolyl-4-hydroxylase for identification of fibroblasts ${ }^{1213}$; and anti-human insulin like growth factor (IGF)-I (Upstate Biology Inc, Lake Placid, New York, USA) which is specific to IGF-I (95\%) but has 5\% cross reactivity to IGF-3. ${ }^{1415}$ Turkey antihuman transforming growth factor $\beta_{1}\left(\mathrm{TGF}-\beta_{1}\right)$ and goat anti-human platelet derived growth factor (PDGF) were obtained from Collaborative Research Corp (Bedford, Massachusetts, USA). Sections were incubated with a turkey antibody raised against a peptide corresponding to the first 30 amino acids of mature TGF- $\beta_{1}$ LC (1-30) which was affinity purified against TGF- $\beta_{1}{ }^{16}{ }^{17}$ Goat anti-human PDGF antibody reacts with all three dimeric forms of PDGF and has been shown to be effective on cryostat sections. ${ }^{1819}$

Optimum dilutions of the antibodies were 1:20 for anti-EG1, 1:30 for anti-EG2, 1:10 for anti-human fibroblast, 1:10 for anti-IGF-I, 1: 10 for anti-TGF- $\beta_{1}$, and 1:50 for anti-PDGF. The sections were rinsed in PBS and then the appropriate biotinylated immunoglobulin G was applied for each monoclonal antibody: goat anti-mouse IgG (Biosource International, Camarillo, California, USA) at a dilution of 1 : 100, goat anti-turkey IgG (Southern Biotech Associates Inc, Birmingham, Alabama, USA) at 1:200, and goat anti-rabbit IgG (Southern Biotech) at 1:400 for 60 minutes. The peroxidase reaction was developed in 3.3'-diaminobenzidine (DAB) $4 \mathrm{HCl}(2.0 \mathrm{mg} / 1$ in Tris buffer) containing $0.03 \% \quad \mathrm{H}_{2} \mathrm{O}_{2}$ and $\mathrm{NaN}_{3}$ $(6.5 \mathrm{mg} / \mathrm{l})$. Finally, sections were counterstained with haematoxylin and, after being washed in running water, dried with alcohol and treated with xylol. System and specificity controls were included in each staining run using human tonsil obtained from a tonsillectomy. Negative controls were performed by substitution of the primary antibodies with the same concentration of mouse, turkey or goat non-immune globulin $\mathrm{G}$ antibodies.

\section{ELECTRON MICROSCOPY}

After several changes of buffer the tissue was post-fixed in $1 \%$ osmium tetroxide in cacodylate buffer for 90 minutes at room temperature, dehydrated through ethanol, and finally embedded in epoxy resin. Sections $1 \mu \mathrm{m}$ thick were cut and stained with toluidine blue to determine the orientation of the biopsy by light microscopy. Sections $90 \mathrm{~nm}$ thick were stained with uranyl acetate and lead citrate on 300 mesh copper grids for electron microscopic analysis (JEM-1200EX, Japan Electron, Japan).

\section{QUANTITATION}

To avoid observer bias, all microscopic slides and electron micrographs were coded prior to analysis by one observer and read blind. The thickness of "total" epithelial basement membrane was assessed on two sections stained with haematoxylin-eosin and was measured from the base of the bronchial epithelium to the outer limit of the reticular lamina of the basement membrane at regular intervals of $200 \mu \mathrm{m}$ along the length of each section using an Olympus BHS microscope at a magnification of $\times 400$. The final result was the mean of all the measurements obtained for each biopsy specimen. The thickness of true basement membrane was determined from three consecutive electron micrographs for each subject at a final magnification of $\times 20000$. The "true" basement membrane, which refers to the lamina rara and densa, was measured from the base of the bronchial epithelium to the edge of the lamina densa adjacent to the underlying reticular layer. Two measurements were performed for each electron micrograph at regular intervals of $5.0 \mu \mathrm{m}$ and the final result was calculated as the average of all the measurements obtained for each subject.

The number of eosinophils and fibroblasts was counted in the submucosal area at a depth 
of $100 \mu \mathrm{m}$ beneath the epithelial basement membrane, excluding glandular and vascular tissues, at a magnification of $\times 400$. Reliable counting in the epithelium was not possible as a consequence of epithelial damage. The total area of examined mucosa was calculated by delineating the area of the section on a Video Micro Meter System (VM-31, Olympus) and using software for area measurements (Analytical Measuring System, Olympus). The results were expressed as the number of positive cells per square millimetre of submucosa.

The Analytical Measuring System was employed to quantify the growth factor expression in the tissue. This was carried out on stored images at a total magnification of $\times 100$. The program allowed for correction of uneven illumination of the field of view and for operatorcontrolled editing of the image. Measurements of the total tissue area of the field were first recorded. The threshold for positive growth factor staining was determined and the area of growth factor measured. The percentage growth factor expression of the tissue was then calculated.

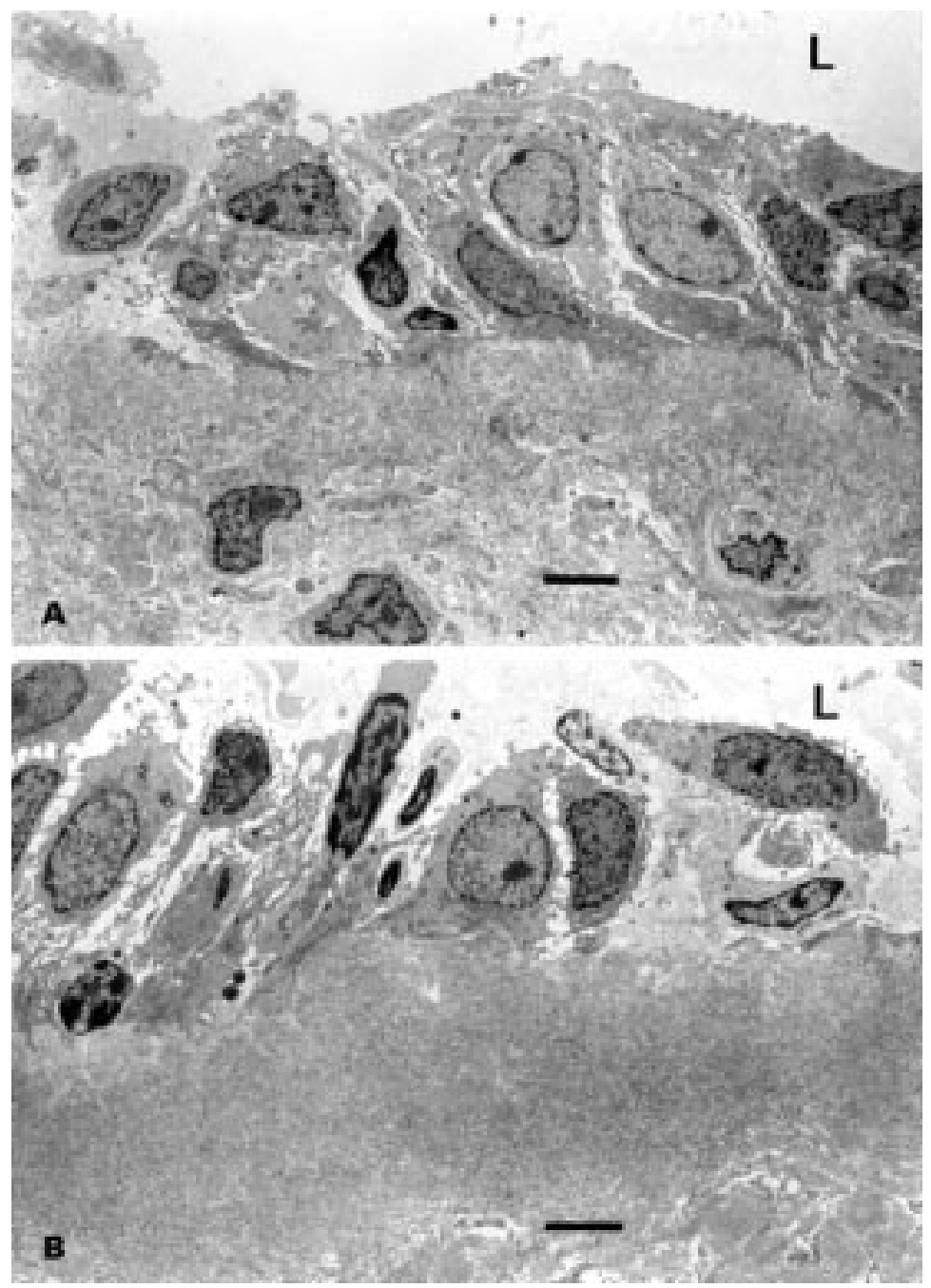

Figure 1 Transmission electron micrograph of the basement membrane region of bronchial biopsy specimens from (A) a control subject and (B) an asthmatic subject showing an increase in the thickness and density of subepithelial collagen in the asthmatic subject. $L=$ lumen. Original magnification $\times 3600 ;$ bar $=5 \mu \mathrm{m}$.
Table 2 Mean (range) thickness of subepithelial layer and basement membrane of bronchial biopsy specimens in asthmatic and control subjects

\begin{tabular}{lll}
\hline & $\begin{array}{l}\text { Subepithelial layer } \\
(\mu \mathrm{m})\end{array}$ & $\begin{array}{l}\text { Basement membrane } \\
(\mu \mathrm{m})\end{array}$ \\
\hline Asthma & $8.09 *(6.4-11.8)(\mathrm{n}=21)$ & $0.13(0.1-0.15)(\mathrm{n}=16)$ \\
Control & $4.02(3.7-4.6)(\mathrm{n}=8)$ & $0.12(0.1-0.14)(\mathrm{n}=8)$
\end{tabular}

* Significantly different from value of control subjects $(\mathrm{p}<0.05)$.

STATISTICAL ANALYSIS

Clinical data are expressed as mean (SD). The results for clinical data were normally distributed and were analysed using a two-sample Student's $t$ test. The thickness of the basement membrane, the number of positive cells, and the percentage of growth factor expression showed a positive skewed distribution. Nonparametric data are expressed as median values and range. Differences between groups were analysed using the Mann-Whitney U test. Spearman's rank correlation coefficient was used to examine the association of histological parameters with clinical data, pulmonary function, and airway sensitivity. Probability values of $p<0.05$ were accepted as significant. Intraobserver reproducibility was assessed using the coefficient of variation and at least three replicate measurements of morphometric parameters were performed by the same observer. The coefficient of repeatability, as described by Bland and Altman, ${ }^{20}$ was used to compare measurements. The mean coefficient variation for repeated measurements was $5 \%$ for thickness of basement membrane, 7\% for EG1, 8\% for EG2, $11 \%$ for fibroblasts, and $9-15 \%$ for growth factor expression.

\section{Results}

Bronchoscopic examination with endobronchial biopsy specimens was performed successfully and was well tolerated in all subjects. Biopsy material for electron microscopy was not adequate to determine the thickening of "true" basement membrane in five asthmatic subjects. The subepithelial layer was significantly thicker in the biopsies taken from the asthmatic subjects compared with the control subjects ( $p<0.05$; table 2). Electron microscopy showed that this difference was due to the underlying reticular layer since the thickness of the "true" basement membrane was similar between asthmatic and control subjects (fig 1).

Immunostaining for eosinophils and fibroblasts clearly demonstrated that both were present in the bronchial epithelium and submucosa. The numbers of EG1 + and EG2 + eosinophils were significantly higher in the biopsy specimens taken from the asthmatic subjects than in those taken from the control subjects $\left(\mathrm{EG} 1+\right.$, median 52.0 cells $/ \mathrm{mm}^{2}$ (range 16-172) versus 2.0 cells $/ \mathrm{mm}^{2}$ (range $0-5$ ), $\mathrm{p}<0.001 ; \mathrm{EG} 2+, 56.0$ cells $/ \mathrm{mm}^{2}$ (range 11165) versus 1.5 cells $/ \mathrm{mm}^{2}$ (range $0-5$ ), $\mathrm{p}<0.001)$. The number of fibroblasts in the submucosa was also significantly higher in the asthmatic subjects (median 42.0 cells $/ \mathrm{mm}^{2}$ (range 13-90)) than in the control subjects (median 18.0 cells $/ \mathrm{mm}^{2}$ (range $4-35$ ), $\mathrm{p}<0.01$ ). 


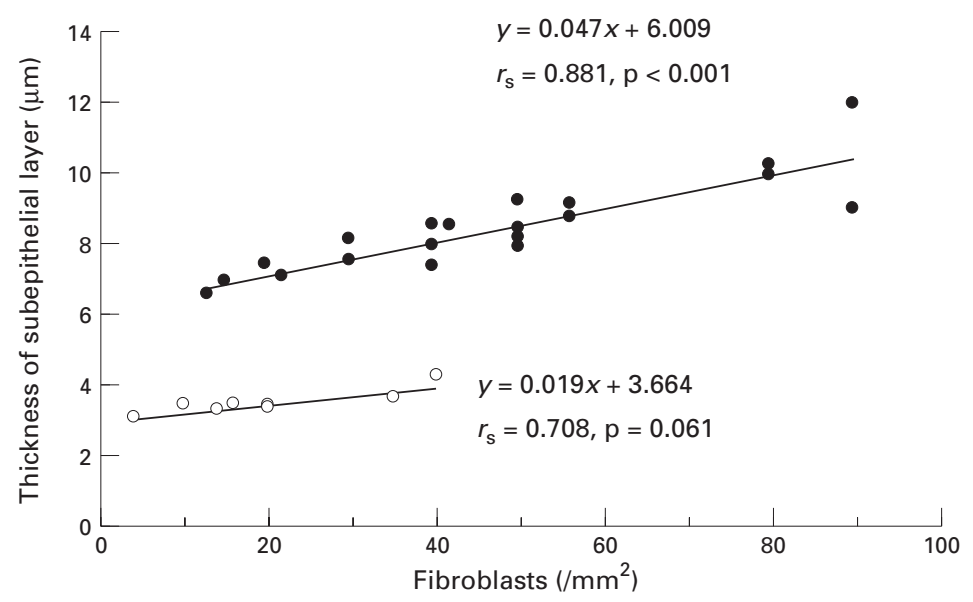

Figure 2 Correlation between the thickness of the subepithelial collagen and the number of fibroblasts per square millimetre of bronchial mucosa. $=$ patients with asthma; $\bigcirc=$ controls.

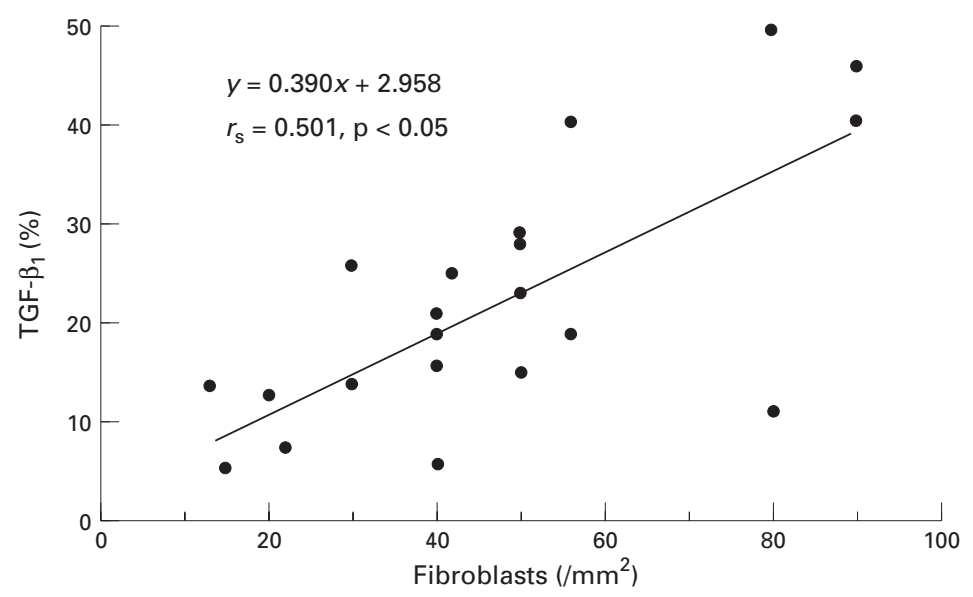

Figure 3 Correlation between the expression of TGF- $\beta_{1}$ and the number of fibroblasts per square millimetre of bronchial mucosa in asthmatic patients.

The degree of thickness of the subepithelial layer correlated with the number of fibroblasts for the asthmatic subjects $\left(r_{S}=0.88, p<0.001\right)$ but not for the control subjects $\left(\mathrm{r}_{\mathrm{S}}=0.70, \mathrm{p}=\right.$ 0.06 ) (fig 2). Immunostaining of cryostat sections with the anti-human TGF- $\beta_{1}$ LC (1-30) detected the presence of the TGF- $\beta_{1}$ precursor molecule in the bronchial epithelium, the submucosa, and the airway smooth muscle. PDGF was detected in the epithelial cells and the inflammatory cells in the submucosa. The pattern of IGF-I distribution showed localisation to the epithelial cells, smooth muscle, and extracellular matrix. No significant differences were observed in the expression of growth factors between asthmatic and control subjects (median TGF- $\beta_{1} 18.0 \%$ (range $5-48 \%$ ) versus $16.0 \%$ (range $7-33 \%$ ), PDGF $37.0 \%$ (range $20-60 \%$ ) versus $32.5 \%$ (range $20-45 \%$ ), IGFI $15.0 \%$ (range $5-31 \%$ ) versus $8.0 \%$ (range $3-32 \%)$ ). The number of fibroblasts correlated with the expression of TGF- $\beta_{1} \quad\left(r_{S}=0.50\right.$, $\mathrm{p}<0.05$ ) (fig 3 ) but not with that of PDGF or IGF-I.

The duration of the clinical disease, diurnal $\mathrm{PEF}$, and $\mathrm{FEV}_{1}$ were not related to the degree
Table 3 Correlation between the thickness of the subepithelial layer and clinical and pulmonary function data

\begin{tabular}{lll}
\hline & $r_{\mathrm{s}}$ & $p$ value \\
\hline Duration of asthma & $2.24 \times 10^{-5}$ & 0.983 \\
Score & 0.586 & $5.15 \times 10^{-5}$ \\
PEF diurnal & 0.175 & 0.058 \\
FEV $_{1}(\%$ pred $)$ & 0.085 & 0.198 \\
Dmin $^{-0.653}$ & 0.001 \\
\hline
\end{tabular}

Score $=$ attack score (daily mean of the sum of 8 symptoms); $\mathrm{PEF}$ diurnal $=$ diurnal variation of peak expiratory flow; Dmin $=$
minimum dose of methacholine as the indicator for bronchial sensitivity.

of thickening of the subepithelial layer, whereas there was a significant positive correlation between attack score and subepithelial thickness in asthmatic subjects $\left(r_{S}=0.58, p<0.001\right)$. Moreover, the degree of thickening was significantly inversely correlated with the bronchial responsiveness represented by the Dmin $\left(\mathrm{r}_{\mathrm{s}}=-0.65, \mathrm{p}<0.001\right.$; table 3$)$.

\section{Discussion}

When the basement membrane thickening observed by light microscopy in the bronchial asthmatic subjects was examined by electron microscopy, the true basement membrane was found to be preserved and the lamina reticularis beneath it had increased in thickness. This increase in thickness correlated with the number of fibroblasts in the bronchial mucosa. These results are in agreement with those previously reported ${ }^{568}$ and suggest that fibroblasts are the cells responsible for the characteristic subepithelial fibrosis observed in asthma and that this phenomenon represents a repair mechanism rather than a regeneration process by the epithelium. Thus, subepithelial collagen thickening may be considered a part of the inflammatory response to the offending agent ${ }^{21}$ as well as a marker of long lasting structural changes of the airway wall, probably related to the chronicity of the disease. ${ }^{4}$

The increased deposition of extracellular matrix at specific sites in the airway wall in asthma suggests possible parallels in mechanism between asthma and interstitial lung diseases that involve fibrosis. Increased expression of a number of growth factors, notably TGF- $\beta^{22}$ and PDGF, ${ }^{23}$ has been observed in lung fibrosis and may drive the excessive matrix deposition and cell proliferation, respectively, that characterise these diseases. However, the growth factors involved in fibroblast proliferation in vivo remain unknown. TGF- $\beta$ stimulates fibroblast proliferation, ${ }^{24}$ promotes matrix protein synthesis, ${ }^{25}$ and increases the expression of receptors for extracellular matrix. ${ }^{2627}$ PDGF causes fibroblast chemotaxis, fibroblast proliferation, and promotes fibroblast-mediated tissue matrix contraction. ${ }^{28}$ IGF-I is a potent mitogen for fibroblasts and smooth muscle cells, ${ }^{29}$ and is able to stimulate collagen synthesis. ${ }^{30}$ PDGF and IGF-I act as a competence factor and a progression factor for fibroblast proliferation, respectively. ${ }^{3132}$ In the present study no significant difference in the expression of any of the growth factors (TGF$\beta_{1}$, PDGF, or IGF-I) was observed between 
asthmatic and control subjects. A recent study ${ }^{33}$ showed that both the mRNA and protein levels for TGF- $\beta_{1}$ were similar in lung tissue among individuals with asthma, a group of individuals with COPD, and a control group with normal lung function. Furthermore, the number of PDGF positive cells was similar among asthmatic subjects, patients with COPD, and nonobstructed smokers, and PDGF receptor- $\beta$ expression did not appear different between these groups. ${ }^{19}$ Taylor et $a \beta^{34}$ found no increase in alveolar macrophage PDGF- $\beta$ mRNA expression in vivo in asthmatic subjects and suggest that PDGF- $\beta$ production by alveolar macrophages is unlikely to play a central role in the pathogenesis of subepithelial fibrosis in asthma. The IGF-I level in bronchoalveolar fluid from patients with idiopathic pulmonary fibrosis is similar to that in controls. ${ }^{35}$ There have been no reports on IGF-I expression in the bronchial mucosa in asthma.

In the present study a weak significant correlation was found in asthmatic subjects between the number of fibroblasts and the expression of TGF- $\beta_{1}$. The cell types involved in the synthesis of growth factors were not identified because we did not double stain. The pattern of TGF- $\beta_{1}$ expression is similar to that observed by Aubert et al. ${ }^{19}$ Ohno et a ${ }^{36}$ reported that the main source of TGF- $\beta_{1}$ mRNA was eosinophils, suggesting that eosinophils play an important role not only in the pathogenesis of inflammation, but of subepithelial fibrosis in asthmatic airways. We speculate that inflammatory cells (especially eosinophils) produce TGF- $\beta_{1}$ and stimulate fibroblast proliferation. Aubert et al identified cells positive for PDGF protein in asthmatic lung tissues as macrophages. ${ }^{33}$ In the present study IGF-I positive cells were localised to epithelial cells, smooth muscle, and the extracellular matrix of the submucosa. The pattern of distribution of IGF-I is similar to that seen in human fetal lung ${ }^{37}$ and that recently described by Aston et $a{ }^{\beta}$ in lung tissue from patients with idiopathic pulmonary fibrosis.

We have also investigated the effects of inhaled corticosteroids in patients with asthma (unpublished data). After treatment with inhaled corticosteroid we observed a significant decrease in the thickness of the subepithelial collagen. This was accompanied by a significant reduction in the number of fibroblasts and the expression of IGF-I. We speculate that the decrease in collagen thickness following inhalation of corticosteroid was a result of inhibition of transcription of the IGF-I gene.

With respect to the clinical data of the asthmatic subjects, no significant correlation was found between the thickening of the subepithelial layer and duration of disease, diurnal variation of $\mathrm{PEF}$, or $\mathrm{FEV}_{1} \%$. However, the subepithelial layer thickening significantly correlated with the attack score. There was a significant inverse correlation between the subepithelial layer thickening and the threshold of bronchial responsiveness. Our results are in agreement with those of Jeffery et $a l^{39}$ and Chetta et al, ${ }^{40}$ but not with those of Roche et al. ${ }^{5}$ However, some of subjects studied by Roche et al were receiving inhaled corticosteroid therapy. The results of the present study suggest that the subepithelial layer thickening plays a role in promoting bronchial responsiveness. Studies have shown that, when the walls of the small airways thicken, even a small degree of bronchoconstriction has a considerable effect on airway resistance and plays a role in bronchial responsiveness. ${ }^{41}$ Thus, in asthma, suggested infiltration of the airways by inflammatory cells, primarily eosinophils, tissue-damaging proteins cause damage and desquamation of the airway epithelium and bronchial hyperresponsiveness. ${ }^{42}$ Moreover, when chronic persistent inflammation continues, fibroblast proliferation (which is likely to be caused by TGF- $\beta_{1}$ ) leads to collagen deposition, airway remodelling occurs, and asthma is aggravated.

In conclusion, we have shown that the thickening of the subepithelial layer in asthma correlates with the number of fibroblasts and the expression of TGF- $\beta_{1}$. Further studies are required to determine the growth factor sources of this excessive deposition of collagen and how to eradicate fibroblast activation, which will be an important key to the future treatment of asthma.

The authors thank all the subjects who volunteered to participate in this study. This study was partly supported by the ScheringPlough Foundation.

1 Houston JC, de Navasquez S, Trounce J R. A clinical and pathological study of fatal cases of status asthmaticus. Thorax 1953;8:207-13.

2 Dunnill MS. The pathology of asthma with special reference to changes in the bronchial mucosa. F Clin Pathol 1960; to changes

3 Bousquet J, Chanez P, Lacoste JY, et al. Eosinophilic inflammation in asthma. N Engl $\mathcal{F}$ Med 1993;323:1033-9.

Bousquet J, Chanez P, Lacoste JY, et al. Asthma: a disease remodeling the airways. Allergy 1992;47:3-11.

5 Roche WR, Beasley R, Williams J, Holgate ST. Subepithelial fibrosis in the bronchi of asthmatics. Lancet 1989;i:520-4

6 Morina C, Brun J, Coulet M, Betail M, Delage C. Immunopathology of the bronchial mucosa in "late onset" asthma. Clin Allergy 1977; 7:137-45.

7 Cutz E, Levison H, Cooper DM. Ultrastructure of airways in children with asthma. Histopathology 1978;2:407-21

8 Brewster CEP, Howarth PH, Djukanovic R, Wilson J, Holgate ST, Roche WR. Myofibroblasts and subepithelial fibrosis in bronchial asthma. Am $\mathcal{F}$ Respir Cell Mol Biol 1990;3:507-11.

9 Nakamura Y, Tate L, Ertl RF, et al. Bronchial epithelial cells regulate fibroblast proliferation. Am f Physiol 1995; 269:L377-87.

10 American Thoracic Society. Standards for the diagnosis and care of patients with chronic obstructive pulmonary disease (COPD) and asthma. Am Rev Respir Dis 1987;136:225-44.

11 Takishima T, Hida W, Sasaki H, Suzuki S, Sasaki T. Directwriting recorder of the dose-response curves of the airway to methacholine. Chest $1981 ; 80: 600-6$.

12 Höyhtyä M, Myllylä R, Piuva J, Kivirikko KI, Tryggvason $\mathrm{K}$. Monoclonal antibodies to human prolyl 4-hydroxylase. Eur F Biochem 1984;141:477-82.

13 Koivu J, Myllylä R, Helaakoski T, Pihlajaniemi T, Tasanen $\mathrm{K}$, Kivirikko KI. A single polypeptide acts both as the $\beta$ subunit of prolyl 4-hydroxylase and as a protein disulfide isomerase. F Biol Chem 1987;262:6447-9.

14 Svoboda ME, Van Wyk JJ, Klapper DG, Fellows RE, Grissom FE, Schlueter RJ. Purification of somatomedin-C from human plasma: chemical and biological properties, partial sequence analysis, and relationship to other somatomedins. Biochemistry 1980;19:790-9.

15 Han VKM, D'Ercole AJ, Lund PK. Cellular localization of somatomedin (insulin-like growth factor) messenger RNA in the human fetus. Science 1987;236:193-7.

16 Khalil N, Bereznay O, Sporn M, Greenberg A. Macrophage production of transforming growth factor $\beta$ and fibroblast production of transforming growth factor $\beta$ and fibroblast
collagen synthesis in chronic pulmonary inflammation. $\mathcal{f}$ collagen synthesis in chronic
Exp Med 1989;170:727-37.

17 Flanders KC, Thompson NL, Cissel DS, et al. Transforming growth factor- $\beta 1$ : Histochemical localization with antibodies to different epitopes. F Cell Biol 1989;108:653-60.

18 Hertz MI, Henke CA, Nakhleh RE, et al. Obliterative bronchiolitis after lung transplantation: a fibroproliferative disorder associated with platelet-derived growth factor. Proc Natl Acad Sci USA 1992;89:10385-9.

19 Aubert J-D, Hayashi S, Hards J, Bai TR, Pare PD, Hogg C. Platelet-derived growth factor and its receptor in lung 
from patients with asthma and chronic airflow obstruction. Am f Physiol 1994;266:L655-63.

20 Bland JM, Altman DG. Statistical methods for assessing agreement between two methods of clinical measurement. Lancet 1986;i:307-10.

21 Holgate ST, Djukanovic R, Howarth PH, Montefort S, Roche W. The T cell and the airway's fibrotic response in asthma. Chest 1993;103:125-8S.

22 Khalil N, O'Connor RN, Unruh HW, et al. Increased production and immunohistochemical localization of transforming growth factor- $\beta$ in idiopathic pulmonary fibrosis. Am 7 Respir Cell Mol Biol 1991;5:155-62.

23 Martinet Y, Rom WN, Grotendorst GR, Martin GR, Crystal RG. Exaggerated spontaneous release of platelet-derived growth factor by alveolar macrophages from patients with idiopathic pulmonary fibrosis. $N$ Engl f Med 1987;317: idiopathic

24 Hill DJ, Strain AJ, Elstow SF, Swenne I, Milner RDG. Bifunctional action of transforming growth factor- $\beta$ on DNA synthesis in early passage human fetal fibroblasts. F Cell Physiol 1986;128:322-8.

25 Ignotz RA, Massague J. Transforming growth factor-beta stimulates the expression of fibronectin and collagen and their incorporation into the extracellular matrix. $\mathcal{F}$ Biol Chem 1986;261:4337-45.

26 Roberts C, Birkenmeier TM, McQuillan JJ, et al. Transforming growth factor $\beta$ stimulates the expression of fibronectin and of both subunits of the human fibronectin receptor by cultured human lung fibroblasts. $\mathrm{F} \mathrm{Biol} \mathrm{Chem}$ 1988;263:4586-92.

27 Ignotz RA, Heino J, Massague J. Regulation of cell adhesion receptors by transforming growth factor- $\beta$. F Biol Chem 1988;264:389-92.

28 Yamakage A, Kikuchi K, Smith EA, LeRoy EC, Trojanowska $M$. Selective upregulation of platelet-derived janowska $M$. Selective upregulation of platelet-derived growth factor $\alpha$ receptors by transforming growth factor $\beta$

29 Clemmons DR, Van Wyk JJ. Evidence for a functional role of endogenously produced somatomedin like peptides in the regulation of DNA synthesis in cultured human fibroblasts porcine smooth muscle cells. F Clin Invest 1985; 75:1914-8.

30 Cambrey AD, Kwon OJ, Gray AJ, et al. Insulin-like growth factor I is a major fibroblast mitogen produced by primary cultures of human airway epithelial cells. Clin Sci 1995; 89:611-7.

31 Thornton SC, Robbins JM, Penny R, Breit SN. Fibroblast growth factors in connective tissue disease associated interstitial lung disease. Clin Exp Immunol 1992;90:447-52.

32 Rom WN, Basset P, Fells GA, Nukiwa T, Trapnell BC, Crystal RG. Alveolar macrophages release an insulin-like
growth factor I-type molecule. F Clin Invest 1988;82: 1685-93.

33 Aubert J-D, Dalal BI, Bai TR, Roberts CR, Hayashi S, Hogg JC. Transforming growth factor $\beta_{1}$ gene expression in human airways. Thorax 1994;49.225-32.

34 Taylor IK, Sorooshian M, Wangoo A, et al. Platelet-derived growth factor- $\beta$ mRNA in human alveolar macrophages in vivo in asthma. Eur Respir f 1994;7:1966-72.

35 Aston C, Jagirdar J, Lee TC, Hur T, Hintz RL, Rom WN. Enhanced insulin-like growth factor molecules in idiopathic pulmonary fibrosis. Am $\mathcal{f}$ Respir Crit Care Med 1995;151:1597-603.

36 Ohno I, Lea RG, Flanders KC, et al. Eosinophils in chronically inflamed human upper airway tissues express transforming growth factor $\beta_{1}$ gene $\left(\mathrm{TGF}-\beta_{1}\right)$. $\mathcal{F}$ Clin Inves 1992;89:1662-8

37 Han VKM, Hill DJ, Strain AJ, et al. Identification of somatomedin/insulin-like growth factor immunoreactive cells in the human fetus. Pediatr Res 1987;22:245-9.

38 Aston C, Jagirdar J, Lee TC, Hur T, Hintz RL, Rom WN. Enhanced insulin-like growth factor molecules in idiopathic pulmonary fibrosis. Am 7 Respir Crit Care Med 1995;151:1597-603.

39 Jeffery PK, Wardlaw AJ, Nelson FC, Collins JV, Kay AB. Bronchial biopsies in asthma. An ultrastructural, quantitative study and correlation with hyperreactivity. Am Rev Respir Dis 1989;140:1745-53.

40 Chetta A, Foresi A, Donno MD, et al. Bronchial responsiveness to distilled water and methacholine and its relationship to inflammation and remodeling of the airways in asthma. Am f Respir Crit Care Med 1996;153:910-7.

41 Wiggs BR, Bosken C, Pare PD, James A, Hogg JC. A model Wiggs BR, Bosken C, Pare PD, James A, Hogg JC. A model
of airway narrowing in asthma and in chronic obstructive pulmonary disease. Am Rev Respir Dis 1992;145:1251-8.

42 Motojima S, Frigas E, Loegering DA, Gleich GJ. Toxicity of eosinophil cationic proteins for guinea pig tracheal epithelium in vitro. Am Rev Respir Dis 1989;139:801-5. 